\title{
Cinsel İstismar Olgusu ve Mahremiyet Eğitimi
}

\author{
Adem Güneş
}

Öz: Genel bir tanımla cinsel istismar, istemediği halde bireylerden cinsel olarak istifade edilmesidir. Taciz, laf atma, teşhircilik gibi boyutlarından başlayarak pedofili ve ensest gibi etkileri daha ağır olan çeşitlerine varıncaya dek cinsel istismar, hukuki, ahlaki ve dini bir suçtur. Alan araştırmaları, bu olgunun, bu olgunun toplumda azımsanmayacak oranda olduğunu ve giderek de arttığını gözler önüne sermektedir. Cinsel istismar özellikle çocuklar üzerinde vuku bulduğunda, hayatın erken dönemlerinde büyük manevi yıkımlara sebep olmaktadır. Cinsel istismar bir mahremiyet eğitimi problemidir. Mağdurun bedensel mahremiyeti çiğnenerek gerçekleşen bir olaydır. Mahremiyeti bilgi, mekân ve beden mahremiyeti olarak alt bölümlere ayırmak mümkündür. Toplumsal ahlaki çözülmenin bir çıktısı olan cinsel istismar olaylarındaki artışlarda en önemli pay mahremiyet algısındaki bozulmalar ve bununla birlikte mahremiyet eğitimindeki yetersizliklerdir. Nitelikli bir mahremiyet eğitimi toplumda cinsel istismar gibi bir olgunun azalmasına katkı sunmaktan öte, yaşamı başkasının manevi sınırlarını ihlal etmeden ilahi iradeye uygun ve insanca yaşamaya imkân oluşturur. Bu çalışmanın amac1, cinsel istismar olgusunun, mahremiyet ve eğitimiyle olan ilişkisini ortaya koymaktır. Çalışmada önce toplumda cinsel istismar olgusunun durumu ve bu sorunun kaynakları daha önce yapılmış araştırma verileriyle tespit edilmiş, daha sonra mahremiyet olgusunun genel ve dini çerçevesi çizilerek, mahremiyet eğitimine dair önemli prensipler ortaya konmuştur. Cinsel istismar ve mahremiyet olguları birbiriyle ilişkili şekilde ilk defa bu çalışmada ele alınmıştır.

Anahtar Kelimeler: Cinsel İstismar, aile içi cinsel istismar, cinsel kimlik, mahremiyet, mahremiyet eğitimi.

\begin{abstract}
The general definition of sexual abuse is the sexual utulization of individuals with out their consent. It is a legal, moral and religional crime from the beginning dimension of harrassment and exhibitionism to the more tragic dimensions such as pedophilia and incest. Surveys reveal this phenomenon is not underestimated in the society and is gradually increasing. Sexual abuse, especially when it occurs with children, causes great spiritual destruction in the early stages of life. Sexual abuse is a problem of privacy education. It takes advantage of the pshical intimacy. Privacy can be categorized as information, place and physical. The most significant share of increases in sexual abuse incidents as an output of social moral resolution is the deterioration in the perception of privacy and inadequacy of privacy education. A strong privacy education beyond contributing to the reduction of the phenomenon of sexual abuse in the society, creates the facility to humanely live without violating the spiritual limits of others in according to divine comand. The problem of this study is the relationship of sexual abuse to intimacy and its education. In the study before, the situation of sexual abuse in the society and the sources of this problem were determined by research data. After this the general and religious framework of the privacy phenomenon and important principle about privacy education was revealed.
\end{abstract}

Keywords: Sexual abuse, domestic sexual abuse, sexual identity, privacy, privacy education.

(C) İlmi Etüdler Derneği

DOI: 10.12658/human.society.7.14.M0206

İnsan \& Toplum, 7(2), 2017, 45-70.

insanvetoplum.org 


\section{Giriş: Cinsel İstismarın Tanımı ve Yaygınlığı}

Cinsel istismar, bedensel ve duygusal sonuçları itibariyle birçok istismar türüne göre daha ağır ve daha uzun süreli tahribatlar oluşturmasına rağmen, konuşulmas1, tartışılması ve açığa çıkması/çıkarılması oldukça zor olan bir istismar biçimidir. Kadının veya psikososyal gelişimini tamamlamamış çocukların yetişkin bireyler tarafından cinsel doyum için kullanılması (Kara, Biçer \& Gökalp, 2004, s. 143) şeklinde tanımlanabileceği gibi, kişilerin bedensel mahremiyetine doğrudan ve dolaylı olarak müdahaleye neden olabilecek cinsel içerikli her türlü söz ve davranışı içine alan bir olgu olarak da tanımlanabilir.

Cinsel istismarın temaslı bir davranış olması gerekmez, temassız birçok davranış da bu kapsama girer. Kadın ticareti, fuhuş, taciz, tecavüz, pedofili, ensest, teşhircilik ve röntgencilik, laf atma, istenmeyen nitelikli-fırsatçı dokunmalar, pornografik-cinsel içerikli konuşmalar ve küfürler yoluyla bir diğerine müdahale veya ondan bu yollarla yararlanma gibi birçok fiili içine alan geniş bir kapsama sahiptir (Polat, 2007, s. 24; Aktaş, 2006, s. 34). Gerek Dünya Sağllk Örgütü (WHO, 2002) gerekse Türkiye'nin taraf olduğu bir diğer sözleşme olan Lanzarote Sözleşmesi (2010) ile cinsel istismar ve sömürü türleri sınıflandırılarak cinsel istismar, birçok farklı türü kapsayan geniş bir profilde tanımlanarak uluslararası düzeyde bir kapsam çerçevesi geliştirilmiştir.

Hem dünya geneliyle hem de ülkemizle ilgili istatistikler, cinsel istismar vakalarının yaygınlığını ortaya koymaktadır. Dünya Gençlik Raporu verilerine göre 15 yaş ve altı kızların üçte birinden fazlası cinsel saldırılara uğramaktadır. Çocuk yaşta gerçekleşen bu vakalar sonucu her yıl yaşları 15-19 arasında 13 milyonu az gelişmiş ülkelerde olmak üzere 15 milyon genç kız doğum yapmaktadır (The World’s Youth, 2000). Bir diğer dünya genelindeki araştırmaya göre, cinsel istismara uğrayan her 4 kızdan biri, her 6 erkek çocuktan biri 18 yaşından önce bu durumu yaşamaktadır. Tecavüze uğrayanların ise \%22'si 12 yaşın altındayken, \%32'si 12-17 yaş arasındadırlar (NSVRC, 2017).

Araştırmalar ve bir kısım resmi veriler, cinsel istismar vakalarının ülkemizde giderek arttığını ortaya koymaktadır. Adalet Bakanlığı verilerine göre ülkemizde 2009 yılında 12.720 çocuk, 2011 yılında 16.354 çocuk, 2012 yılında 16.897 çocuk, 2013 yılında 16.938 çocuk cinsel istismara maruz kalmıştır (Adalet Bakanlığı Adli Sicil ve İstatistik Genel Müdürlügü̆, 2013). Bu resmi rakamlara rağmen ülkemizde cinsel istismar vakalarının sıklığına ait verilerin hala tam olarak gün yüzüne çıkmadığı tahmin edilmektedir. Çünkü böylesi bir durumda damgalanmış olmanın getirdiği sorunlar ve istismarın devam etme riski sebebiyle vakaların birçoğu açı̆ga çıkmamaktadır (Savrun, 2006, s. 568). 
Söz konusu araştırma verilerine göre en önemli mağdurlar, diğer istismar türlerinde olduğu gibi çocuklardır. Anlamlandırılması zor olan husus ise çocukların maruz kaldığı cinsel saldırıların yaklaşık yarıya yakın bir kısmının akraba veya tanıdıklar tarafından gerçekleştirilmekte olduğudur (Giddens, 2005, s. 226). Çocuğun veya kadının hayatta karşılaşabileceği fizyolojik veya psikolojik sorunlardan en büyüğü "ensest" olayıdır. Aile içi cinsel bir istismar olarak kabul edilen ensest, evlenmeleri dinen, hukuken ve ahlaken meşru olmayan kişiler arasındaki cinsel yakınlaşmalardır (TDK, 2011, s. 802). Zaten normal olmayan bir durum olan istismarın en uç sınırlarında gerçekleşen bir olay olarak ensestin bir de çocuk üzerinde vuku bulması, bu olguyu mahiyet itibariyle bir insanlık sorununa dönüştürmektedir. Bu olay istismarcının bir fırsat davranışı olarak görülebileceği gibi, kontrol edemediği cinsel güdülerini aile içinde ve yakın çevresinde uygun bulduğu zayıf bir kişide tatmin etmesi şeklinde de değerlendirilebilir.

Ülkemizde, mahkemelere yansıyan sınırlı sayıda aile içi cinsel istismar vakalarının ortaya koyduğu sonuçlara göre, kız çocukları erkek çocuklara göre daha fazla istismara maruz kalırken ve bu istismarlar sırasıyla öz baba, üvey baba, kardeş, amca ve diğer yakınlardan gelmektedir. Ayrıca üvey babaların rol oynadığı istismarlar diğerlerine göre daha ağır ve daha uzun olabilmektedir (Topçu, 1997, s. 96). Ortaya çıkan bu vakalar, gerçekte ensest olgusunun ancak \%10 gibi (Polat, 2001, s. 223) sınırlı bir kısmını oluşturduğu, gizli kalan gerçek boyutlarını ise tahmin etmenin oldukça zor olduğunu düşündürmektedir.

Kadının Statüsü Genel Müdürlügü̈nün 13 bine yakın kadın üzerinde gerçekleştirdiği araştırmadaki bulgular, yukarıda verilen dünya genelinde yapılan araştırmalardaki istismara uğrama yaşı ile uygunluk arz etmektedir. Buna göre kadınların \%7'si 15 yaşından önce cinsel istismara maruz kalmaktadır. Bunun \%42'sini tanımadıkları kişiler, \%30'unu ise yakın erkek akrabalar gerçekleştirmiştir. Kadınların \%9,6’sının babası tarafından, \%6.1'inin erkek kardeşi/ağabeyi tarafından ve \%2.5'inin üvey babası tarafından 15 yaşından önce cinsel istismara uğradığı görülmektedir (KSGM, 2009, s. 65, 220). Üniversite öğrencileri arasında yapılmış bir araştırmaya göre ise, çocukluk çağında ensest dâhil cinsel istismar olaylarından herhangi biri ile karşılaşma oranı \%10, sadece ensestle karşılaşma oranı ise \% 4,6’dır (Taşçı, 2010, s. 118). Psikiyatri kliniğine başvuran kadın hastalar arasında yapılmış bir başka araştırma sonucu da, çocuklukta cinsel istismar görülme oranı \%13,3’ü ensest olmak üzere \%22 olarak tespit etmiştir (bkz. Yanık, 2000). Üç farklı araştırma verilerinin ortaya koyduğu sonuca göre kadınların çocukluk çağında cinsel istismara uğrama oranı ortalama \%10'un üzerinde ve bunun önemli bir oran1- 
nı ensest vakaları oluşturmaktadır. Bu da göstermektedir ki gerek aile içi gerekse genel boyutlarıyla cinsel istismar, sosyal/ahlaki/dini açıdan toplumu tehdit eden ciddi bir problem haline gelmiştir.

Aile içi cinsel istismarın en fazla mağduru olarak çocukların, yakınları tarafından istismara uğradığının farkına varmaları uzun bir zaman alabilmektedir. Durumu anladıklarında ise karmaşık duygular yaşarlar. Çünkü bunu yapan aslında en değer verdikleri kimseler arasındadır. Bu yüzden bir taraftan nefret ederken diğer taraftan onları sevmeyi sürdürürler. Yuvanın kendileri yüzünden dağılması endişesiyle duruma uzun süre sessiz kalırlar. Bir çocuk için cinsel taciz ne kadar travmatik olsa da, aile içindeki kadar yıkıcı olmamaktadır. Taciz aile içinde yer aldığında aile yapısı genellikle bozulmakta ve çoğunlukla çocuklar aile üyelerini kaybetmektedirler. Bu durum ise onların yaşamlarında büyük travmalara neden olmaktadır (Ziglar, 1998, s. 327).

Cinsel istismara maruz kalan çocuk ve kadınlar, diğer istismar türlerinin neden olduğu korku, endişe, antisosyal kişilik özellikleri gibi olumsuzlukları kazanmanın yanısıra, ciddi psikolojik travmalar, cinsel davranış bozuklukları, stres bozukluklar1, öğrenme yetersizlikleri, hasarlanmış olma hissinin getirdiği suçluluk, çaresizlik, düşmanlık gibi birçok duygu ve davranış sorunları da yaşayabilmektedirler (Kara vd., 2004, s. 144). Çoğu zaman ümitsizliğin oluşturduğu bu tür bunalımlara, çözülemeyen inanç ve kader sorgulamaları da katkı yapmaktadır.

\section{Cinsel İstismar ve Ensest Problemini Artıran Faktörler}

Toplumumuzda aile içi cinsel istismar oranlarının giderek artması düşündürücüdür. Bütün dini değerler ve genel ahlak ilkeleriyle zıtlık teşkil eden bu olgu; toplumsal yapının mahrem alanında gizli olması, ifşasının bu mahrem alana zarar vereceği, aile içinde olanın yine ailede halledilmesi gerektiği ve ortaya çıktığında meydana gelecek sonuçların olayın kendisinden daha kötü olması gibi, birçok toplumsal algı ve kaygıdan dolayı gündemden uzak tutulan bir problem olmuştur. Kültürel gelenekte kimi zaman kurbanın sebep olduğu bir olaymış gibi düşünülmesi de bu durumun pekişmesine yardımcı olmaktadır. Yalnız bugünün meselesi olmayan tarihsel süreçte farklı toplumlarda tezahür etmiş olan ensest olgusuna İslam'ın bakış1 ${ }^{1}$

1 Kur'an'da Nisa Sûresi 22-23. ayetlerde cinsel ilişkinin haram kılındığı yakın aile fertleri tek tek belirtilmiştir: "Geçmişte olanlar hariç, artık babalarınızın evlendiği kadınlarla evlenmeyin. Çünkü bu bir hayâsızlık, öfke ve nefret gerektiren bir iştir. Bu, ne kötü bir yoldur. Size şunlarla evlenmek haram kılındı: Analarınız, kızlarınız, kız kardeşleriniz, halalarınız, teyzeleriniz, erkek kardeş kızları, kız kardeş kızla- 
kesin olmakla beraber, bu durumun bireysel bir problem olmanin ötesinde sosyal bir sorun olarak, Müslüman toplum adına yeniden düşünülmesi ve irdelenmesi bir zaruret olarak gözükmektedir.

$\mathrm{Bu}$ bağlamda gerek aile içi gerekse aile dışında cinsel istismar problemlerinin artışında genel olarak şu faktörlerin etkili olduğunu belirtmeliyiz:

- Aile yapısı ve algısındaki değişimler ve anne-baba tutumları,

- Giderek artan ve kontrolsüz bir hale gelen ve hayatımızı kuşatan cinsel uyarıcıların meydana getirdiği sürekli tahrik etkisi,

- Akıl-duygu dengesi bağlamında, şehevi duyguların benliğe hâkimiyeti veya cinsel ağırlıklı benlik problemleri,

- Tüketim zihniyeti karşısında zayıflayan dini-ahlaki-sosyal değerler,

- Mahremiyet algısındaki değişimler gibi birçok faktör, bu problemin tartışılması gereken bazı boyutlarını ifade etmektedir

Problem aşağıda bu faktörler açısından ele alınmıştır.

\section{Cinsel Kimlik Problemleri ve Ebeveyn Etkileri}

Cinsel kimlik ya da cinsiyet rolü eril ya da dişil olarak etiketlenebilen davranışları, tutumları, değerleri, düşünme biçimlerini, konuşmayı, oturmayı ya da yürümeyi, giyinmeyi, kişinin bedenini süslemesini kapsar. Bireyler erken yaşlardan itibaren cinsiyet kimliklerini erkek ve kadınsal olarak anlamayı öğrenirler. İki farklı rolü nelerin oluşturduğuna ilişkin anlamları, kavramları ve davranışları benimserler. Bu gelişimde en önemli pay, anne-baba merkezinde toplumsal ve kültürel etkilerdedir (Gander \& Gandier, 1995, s. 296).

Cinsel saldırıların cinsel kimlik ile doğrudan bir ilişkisi mevcuttur. Bu saldırılar, cinsel ihtiyaç ve gerginliğin giderilmesi adına yapılan ve aniden ortaya çıkan eylemler değildir (Atkinson \& Hilgard, 2003, s. 378). Aslında bu durum istismarcının bir kişilik problemidir ve fiilin önceden planlanması söz konusudur. Bu yolla bir taraftan mağdura şiddet gösterilip onun korkutulması, sindirilmesi ve yenik düşmesi sağlanırken diğer taraftan eylemin bu haliyle cinsel doyuma ulaşma isteği

rl, sizi emziren sütanneleriniz, süt kız kardeşleriniz, karılarınızın anneleri, kendileriyle zifafa girdiğiniz karılarınızdan olup evlerinizde bulunan üvey kızlarınız, -eğer anneleri ile zifafa girmemişseniz onlarla evlenmenizde size bir günah yoktur- öz oğullarınızın karıları, iki kız kardeşi (nikâh altında) bir araya getirmeniz. Ancak geçenler (önceden yapılan bu tür evlilikler) başka. Şüphesiz Allah çok bağışlayıcıdır, çok merhamet edicidir." Ayrıca İslam'ın ensest olgusuna bakışı için bkz. Kasapoğlu (2003, s. 5-15). 
söz konusudur (Köknel, 2013, s. 19). Böylesi bir ruh halinde, normal şekilde tatmin olamayan veya tatmin imkânı bulamayan cinsel arzuların sadistik bir yolla tatmini tercih edilen bir durumdur. Sadizm ise, cinsellikle şiddeti bir araya getirmektir. Aslında bu cinsel sadizmdir. Fromm bunun dişında bedensel ve ruhsal sadizmden de söz eder (Fromm, 2011, s. 32). Anlaşılacağ gibi bedensel ve ruhsal sadizm başkalarına fiziki veya manevi olarak eziyet çektirmektir. Buradaki önemli nokta, istismarcının gösterdiği cinsel sadizmin, erken yaşlarda maruz kaldığı bedensel ve ruhsal sadizmle bir ilgisinin olduğudur. Bu şekilde, bireyin kişiliğinin (sadizmde olduğu gibi) normal sınırların dışına çıkmasıyla, cinsel anlamda da anormal olanı arzulaması arasında bir bağ olduğu ortaya çıkmaktadır.

Suçlu gençler arasında yapılan bir araştırmaya göre gençlerin \%7'sinin cinsel saplantılı olduğu görülmüştür. Cinsel suçluların oranı ise \%31 kadardır. Cinsel suçlu grubunun \%60'ını eşcinsel suçları, kalanını tecavüz ve kız kaçırma gibi suçlar takip etmektedir (Yavuzer, 1998, s. 197). Cinsel suçlara bulaşanlar genelde, sevgi ve disiplin eksikliği olan ve ihmalin var olduğu ailelerden gelirler. Kendi verdikleri bilgilere göre, ailelerinde bozuk ilişkiler hâkimdir. Anne babalarından ve evli olanlar eşlerinden yeterince sevgi görmemişlerdir. Kişiliklerine saygı duyulmadığı gibi, eziyet ve işkence görmüşlerdir (Çağlar, 1981, s. 181).

Eşcinsellerle ilgili bir araştırma sonucu da bu durumu destekler niteliktedir. Kırk eşcinsel erkek üzerinde yapılan bir araştırmaya göre, bunların neredeyse tamamının, babasıyla sevgi ve ilgiye dayalı bir iletişimi olmamıştır. Evlerinde baba çok pasif kişilik sergilerken kararları genellikle baskın karakterli anneler almış ve bu kişiler, erkeklere has bir takım faaliyetlerde babalarının eksikliğini sürekli hissetmişlerdir. Kadın eşcinsellerde ise, durum bunun tersi şeklinde gelişmiş, baskın karakterli babanın kız çocuğunu erkek gibi yetiştirmesi söz konusu olmuştur (Ziglar, 1998, s. 320).

Örneklerin işaret ettiği gibi, cinsel sapma ve suçların ortaya çıkmasında önemli bir faktör "cinsel kimlik bocalaması"dır. Cinsel kimliğin temelleri çok erken yaşlarda atılmaktadır. Üç yaşına vardıklarında çocuklar cinsiyetlerinin farkına varır, hatta cinsiyetleriyle övünme eğilimindedirler. Duygu ve davranış olarak bu çağda başlayan cinsel kimlik oluşumu ergenlik çağına kadar sürer (Jersild, 1979, s. 210). Çocuğun cinsel kimlik kazanmasında en önemli unsurların başında özdeşim yapması gelir. Bilinçli bir öykünmeden ziyade, anne-babasına özendiği için kadın-erkek tavırlarını taklitle edinir. Oturması, konuşması, giyinişi ve oyunlarında anne-babanın birçok cinsiyet özelliğini kendi kişiliğinde yoğurur. Özdeşimin sağlıklı bir şekilde yürümesi, öncelikle anne ile kız çocuk, baba ile erkek çocuk arasındaki iletişimin yakın ve olumlu olmasına bağlıdır. Yine babanın kızıyla annenin de oğluyla kurdu- 
ğu sevgi temelli yakın iletişim, onların cinsel kimliğinin yerli yerine oturmasına yardım edecektir (Santrock, 2014, s. 250; Adler, 1984, s. 128-139).

Cinsel suç ve istismarlarda bir risk faktörü olduğunu belirttiğimiz cinsel kimlik sorunları, temelde ebeveynin cinsel kimlik ve kişiliğinde düğümlenmektedir. Anne-babalar çocuklarında normal/sağlıklı bir cinsel kimliğin oluşmasını bekliyorlarsa, önce kendi cinsel kimlik ve kişiliklerinin normal çizgide ve mahremiyet temeline oturmuş olmasını sağlamalıdırlar. Çünkü çocuğun cinsel konulardaki eğilim ve duyarlılığı, diğer birçok konuda olduğu gibi, ailedeki anne-baba-çocuk ilişkisine uygun bir biçimde gelişip, bütün yaşam boyunca sürdürülebilmektedir.

\section{Cinsel Uyaricilar ve Medyanin Etkileri}

Cinsel istismar olaylarının artmasına neden olan risk faktörlerinden bir diğeri, başta medya olmak üzere çevreden gelen cinsel içerikli uyarıcılardır. Çocuk, genç ya da yetişkin bütün bireyler, yaşadığımız dünya içerisinde yoğun cinsel uyarıcılara maruz kalmaktadır. Bu uyarıcılar kimi zaman cinselliğin hemen fark edilebileceği bir şekilde açık ve direkt görseller yoluyla, kimi zamanda gizli, bilinçaltına yönelik mesajlarla iletilmektedir. Mahrem alan içerisinde yaşanan cinsellik hayatın bir parçasıyken, sosyal yaşamda bunu ifşa yoluyla herkese açık hale getirmek, onu (ifade edilen diğer faktörlerin etkisiyle de) kişinin kimi zaman kontrol edemediği bir güç ve duygularını etkisinden kurtaramadığı potansiyel bir tehlike haline dönüştürebilmektedir (Pernaud, 1987, s. 201).

Kahraman, cinselliğin bir tüketim malzemesi olarak "iptila” oluşturacak derecede reklam, sanat, edebiyat ve sinema gibi birçok alanda kullanıldığına dikkat çekerek, giderek artan ancak farkında olunmayan cinsellik yayılımının, çağın insanını tutsağı haline getirip yalnızlaştırdığını ifade etmektedir. Ona göre artık mutluluğun kaynağı olarak görülen cinselliğin, arzu ve haz kavramlarıyla yakın bir ilişkisi mevcut. Bu ilişkiyi şu şekilde açıklamaktadır:

\footnotetext{
"Bu şartlar altında her şeyi cinsellikle sinırl görmek o kadar anlamlı değil. Daha önemlisi, bu açılımın, 'arzu' kavramıyla kayıtlı olması. 'Arzu' tüketiciliği beraberinde getiriyor ve buna bağlı olarak cinsellik, tüketim kültürünün bir parçası haline geliyor. Çünkü arzunun ayrılmaz ikizi 'haz', genel olarak tüketimle özdeşleştirilebilen bir olgu. Yemek içmekten, giyinip kuşanmaya, estetik tercihlere kadar her alanın hazla bir ilişkisi var. Kapitalizm ve piyasa sürekli olarak arzunun hazla tatmin edilebileceği izlenimini verecek biçimde kurgular sahneliyor toplumun karşısında." (2010, s. 18, 21).
}

Günümüz modern toplumlarında bütün mahremiyet alanları alenileştirilerek, bedenler tüketilmektedir. Kapitalist sektörler için beden önemli ve sürekli bir tüketim alanıdır. Kapitalizm tüketim hesabını bedenler üzerinden yaparak postmodern 
bir istismar biçimi yürütmektedir. Tüketim uğruna bedenler ufalanmakta, mahremiyet biçilmekte ve bedenler altüst edilmektedir (Okumuş, 2011, s. 54). Bu noktada bir kıyaslama yapacak olursak, eski toplum anlayışında İslam dininin önerdiği gibi arzuların (talep edilen ürünlerin), ihtiyaçlar çerçevesinde ve kanaat ölçüsünde karşılanması anlayışı ön plandayken, yeni toplum anlayışı arzuların, cinselliğin de bir parçası olduğu "hazcılık" prensibi üzerinden karşılanmasını öngörmektedir. Bu durum ise, tüketirken cinsellikle daha sık karşılaşmak anlamına gelmektedir. Haz$\mathrm{c} 1$ /hedonist anlayış, insanı zevk alabileceği şeyleri yapmaya teşvik ve tahrik etmekle beraber, dinî yaşam ve ahlak gibi bireysel ve toplumsal sorumluluk alanlarında, gizli bir duyarsızlaşma ve yavanlaşmayı beraberinde getirmektedir.

Cinselliğe en çok müracaat eden alanlardan biri tüketimin vitrini sayılabilecek olan reklam sektörüdür. Mağaza vitrinleri, sokaktaki reklam bilbordları, sinema afişleri gibi medyanın dışındaki reklam alanlarında kullanılmasına rağmen cinsellik, televizyon reklamlarının vazgeçemediği ana tema durumundadır. Telefon, parfüm, araba, banka, mobilya, tatil reklamlarından süt, çikolata, dondurma hatta peynir reklamlarına varıncaya kadar neredeyse akla gelebilecek her türlü ürün reklaminda cinselliğe rastlamak mümkündür. Amaç izleyiciye en kısa sürede, en etkili mesajı verip dikkatini celp etmektir. Bu konuda Vitale, izleyicisini hipnotize ederek istenen yönde davranışa sevk eden reklamın, başarılı bir reklam olduğunu belirterek, cinsellikte hipnotik bir etki olduğunu ve bu yüzden reklamlarda çok sık kullanıldığını ifade eder (Vitale, 2008, s. 163). Bu durumdan dolayı reklamlar dünyası bir "cinsellik dünyası" olarak da nitelendirilmiştir (Kahraman, 2010, s. 117).

Televizyon reklamlarında dikkat çeken bir diğer nokta, çocuk ürünleriyle ilgili reklamlarda çocuk bedenlerinin kullanılmasıdır. Hatta çocukları kimi zaman yetişkin cinselliğiyle aynı karede görmekte mümkündür. Şampuan, çocuk bezi, bakım ürünleri vs. gibi çocuk bedenlerinin sergilendiği reklamlarda, çocukların yetişkin bir kişilik gibi sunulmasından öte, yetişkin bir cinsel rolle sunumu söz konusudur. Bunların dışında, ürünü sempatik hale getirmek, çocuğu harcamaya dâhil etmek ve ona tüketimci bir kimlik kazandırma gibi niyetlerle, çocukların ilgili olmadıkları ürünlerde bile kullanılmaları söz konusudur. Medyanın çocuklar konusunda hassasiyeti bir kenara bırakarak, çocuk ve cinsel görsellik gibi birbirine mesafeli durması gereken iki şeyi iç içe kullanması, tüketim lehine çocuk istismarı yapmaktan çekinmediğini ortaya koymaktadır.

TV'de her yıl cinselliğin bizzat gösterimi dışında, ayrıca cinsellik çağrışımı yapan milyonlarca sahne yer almaktadır. Bu çağrışımların en çok yapıldığı programlardan biri de mizah programlarıdır. Mizahın sevilen ve istenen bir eğlence haline 
gelmesi için cinsel çağrışımlar, vazgeçilmez bir malzeme olarak görülmektedir. Aynı şekilde müzik klipleri cinselliği ana malzeme olarak kullanan bir başka sektördür. Öyle ki kadın ya da erkek bedenlerini sergilemek konusunda yarış içinde olunan bu alanda, cinsel görüntülerin olmadığı bir ürün bulmak neredeyse imkânsız gibidir. Böylelikle her noktası cinsellikle kuşatılmış olan TV programları, mevcut yapısıyla bireysel ve toplumsal bilinçaltında, cinsellik konusunda sınırları aşmanın önemli bir sorun teşkil etmediği gibi riskli bir algıyı da oluşturmuş olmaktadır.

Görünen veya görünmeyen cinsel istismar olaylarının artmasına katkı yapan önemli bir faktör de internettir. Küresel bir ağ olan internette cinsellik hatta pornografinin hâkim olduğu, yalnız çocuk ve gençler için değil herkes için risk oluşturan kontrolsüz bir alan mevcuttur. Bu pornografik alan, insanlara uç sınırlarda cinsel istekler üreten, bunun yanında bütün cinsel arzuları karşılamayı amaçlayan sapkınlığın sınır tanımaz hale geldiği ve hızla yayıldığı bir alandır. Pornografi, cinselliğin normal sınırlarını aşması ve kadın bedeninin tüketilen bir meta olarak istismara maruz birakılmasıdır (Kahraman, 2010, s. 198). Bu konudaki veriler pornografinin bir ticaret alanı ve büyük bir küresel pazar olduğunu ortaya koymaktadır. Bu ticaretin önemli bir kısmı illegal olmakla birlikte, artık giderek vergilendirilmiş legal bir ticarete döndüğü bildirilmektedir. Saad, 2006 yılında bu pazardaki gelirin yüz milyar dolara yakın olduğunu aktarmaktadır. Bu rakamlar Amerika için üç büyük TV şirketi veya bir futbol liginin gelirinden daha fazla olması anlamına gelmektedir. Yine araştırmalar internet sitelerinin \%12'sinin pornografik sitelerden oluştuğu ve internet trafiğinin \%37-50'sinin bu sitelerle bağlantılı olduğunu ortaya koymaktadır (Saad, 2011, s. 308).

Konuyla ilgili bugünkü istatistiklerin ise, 2006 ve 2008 yıllarına ait bu rakamların çok daha üzerinde olması kuvvetle muhtemeldir. Bu durumun ülkemizdeki yansımasına bakılacak olursa, durumun yukarıdaki verilere uygun geliştiği fark edilecektir. Bilgi Teknolojileri ve İletişim Kurumu'nun 2012 yılında TBMM'ye sunduğu, ülkemizde internetin kullanım biçimiyle ilgili istatistiklerin yer aldığ1 "Güvenli İnternet Kullanımı" isimli resmi rapora göre Türkiye, internet kullanımında dünyada 6. sırada yer almaktadır (BTK, 2012). Raporda bir dakika içerisinde gerçekleştiği belirtilen olaylardan bazıları ise şunlardır: 2 milyon insan pornografik sitelere giriş yapmaktadır. 11 milyon kişi internette sohbet gerçekleştirmekte, iki büyük sosyal paylaşım sitesinde 1 milyon civarında yorum, video ve fotoğraf paylaşılmaktadır. Ve önemli bir kısmı cinsel içerikli olmak üzere 1 milyona yakın arama yapılmaktadır. Mevcut raporun verdiği bu bilgiler, ülkemizdeki doğrudan veya dolaylı pornografik/cinsel içeriğin, genel internet kullanımında kapladığı alan ve durumun etkileri konusunda fikir vermektedir. 
Pornografinin etkisi, bu yayınların giderek artması, çeşitlenmesi ve yayılmasıyla doğrudan ilgilidir. Geçmişte de bu tür yayınlar olduğu sabittir. Ancak bu yayınların somut halden sanal bir zemine kayması, bir taraftan kaynağından çoğaltılmasına ortam sağlarken diğer taraftan bu yayınlara ulaşılmasını oldukça kolaylaştırmıştır. Bizzat insan bedeni üzerinden oluşturulmuş bu endüstri, varlık olarak insanın kıymetine, inancına, duygu ve evrensel değerlerine karşı zevki ve kazancı yegâne amaç edinmiştir. Bu yapı evrensel bir ağla, din, inanç, kültür, millet farkı gözetmeden -Müslüman toplumları da atlamadan- her topluma aynı malzemeyi yenileyerek sunmaktadır. Aslında psikolojik açıdan "sapkınlık" olduğu açıkça belirtilen pornografik cinsel davranışların, bir "cinsel tercih" ya da "cinsel özgürlük" gibi sunulması ise, sorunun bir başka boyutunu ifade etmektedir. Belki de bu durum insana sınırsız özgürlük vadeden postmodern anlayışın, insanın meşru olmayan eğilimlerini de bu özgürlük sınırları içerisinde değerlendirmesi sonucu geliştiğini söylemek yanlış olmaz. Bununla birlikte bu durum, dini, ahlaki ve evrensel değerlerin yasakladığ ve kesin sınırlar çizdiği bu tahrip olgusuna karşı, bireysel ve toplumsal algıların yumuşatılmasına yönelik bir yaklaşım olarak değerlendirilebilir.

Pornografinin bireylerde cinsel yönden yapay olarak tahrik ve bağımllık yaratma etkisinin olması, ruh sağllğı açısından oldukça problemli bir durumdur. Bu tür tahriklerle erken dönemlerde karşılaşılması, çocukların gizli gelişim dönemlerini atlamalarına yol açmaktadır. Daha da ötesi bu etkiler ergen ve gençlerin olgunlaşma sürecini yavaşlatmakta, kimi zaman ise geciktirmekte hatta tamamen engelleyebilmektedir (Ziglar, 1998, s. 303). Pornografinin oluşturduğu ve gizliden seyreden bir bağımlılık, bireyleri cinsellik konusunda doğru ve tabi olanı yapmasını engelleyip, tatmin yolunu aramaya sevk edebilmektedir. Ayrıca bu ruh halinin önemli bir etkisi de, bireylerin bilinçaltında taşıdıkları mahremiyet algılarını olumsuz etkileyerek, her türlü cinsel sapkınlığ edinmesine kadar varabilir (Cline, 2017).

Bunların dışında TV ve internete hayatında önemli bir yer ayıran ergen ve gençlerin yoğun cinsel içerikli mesajlarla karşı karşıya kalması, haliyle onlarda hayatın en önemli malzemesinin "cinsellik ve kadın erkek ilişkileri" olduğu kanısını kuvvetlendirmektedir. Bugünün ergen ve gençleri, cinsel açıdan güç bir ortamda yaşamaktadırlar. Bu yüzden evlilik dışı cinsel birlikteliklerle tanışmaları eskiye oranla daha erken yaşlarda ortaya çımaktadır (Pernoud, 1987, s. 192). Özellikle cinsel ilginin arttığı 14-16 yaşlar arasında maruz kalınan kontrolsüz ve yoğun uyarıcılar, cinsel düşkünlüğe ve psikolojik rahatsızlıklara neden olabilmektedir. Cinselliğe aşırı düşkünlük ise, cinselliğin hâkimiyet kurduğu ruhsal dengede uyumsuzluk ve düzensizliklere, sonuçta da cinsel istismarlara kadar uzanabilmektedir (Çapl,, 1970, s. 229, 231). 


\section{Mahremiyet Olgusundaki Değişimler}

Cinsel istismar olaylarına kaynak oluşturabilecek önemli nedenlerden biri de mahremiyet olgusundaki değişim ve dönüşümlerle birlikte mahremiyet eğitimindeki problemlerdir. Mahremiyet kavramını genel ve özel olarak iki şekilde tanımlamamız mümkündür. Mahremiyet özel anlamda "mahrem" kavramıla ilgilidir. "Haram olmak, haram kılmak ya da haram kılınmış" anlamlarına gelen ve dini bir kavram olarak kullanılan mahrem, aynı zamanda Allah'ın haram kıldığı, yasakladığı ve evlenilmesini meşru kabul etmediği kimseler için kullanılır (DİB, 2010, s. 402). Olgu olarak mahremiyet ise kişiye özel olan, herkese açık olmayan, duyulması, görülmesi ve bilinmesi arzu edilmeyen, belli şartlar dışında dâhil olunmayan, yabancıya kapalı alan olarak tanımlanmaktadır (MEB, 1996, s.1882; Aydın, 2009, s. 61-67).

Tanımların işaret etmiş olduğu gibi mahremiyet, bireye ait özel ve korunaklı olması gereken bir alanı ifade etmektedir. Mahremiyet fitri/evrensel bir olgudur. Yani her bireyin kendine özel olanı koruma içgüdüsü vardır. Ancak bunun karşılığında insanın, gizli olanı merak etme, onu öğrenme arzusu da mevcuttur. Dinler ya da İslamiyet mahremiyet olgusunu toplumdaki sosyal-insani ilişkilerin daha sağlıklı, daha normal yürüyebilmesi için kendi prensipleri doğrultusunda şekillendirmiştir.

Mahremiyet temelde bilgi, mekân ve bedenle doğrudan ilgilidir. Bunların her biri birer mahremiyet alanı olmakla birlikte birbirinden de ayrı değildir. Mahremiyetin omurgasını oluşturan özel hayatın gizliliği, bireysel ve sosyal huzura dayanak teşkil eden temel unsurlardan biri olarak, hem din hem de evrensel hukuk ilkeleri çerçevesinde garanti altına alınmıştır. ${ }^{2}$ İslam dini ise sosyal alanda bireyin ve ailenin huzurunu hedeflemiş ve bu doğrultuda kişiye veya aileye ait sırların ve bu nitelikteki bilgilerin sahibinin izni olmadan afişe edilmesine ya da bizzat kendinin bunu gerekmediği halde magazinsel bir niyetle yapmasına ahlaken müsaade etmemiştir.

Mahremiyetin muhafaza edilmesi ile ilgili olarak Kur'an'in ve Hz. Peygamber'in sunduğu birçok prensip mevcuttur. Aynı zamanda ahlaki bozulmayı önleyici birer koruyucu tedbir niteliğindeki bu prensiplerden önemli olan bazıları şunlardır:

2 Insan Hakları Evrensel Bildirgesi'nin 12. maddesi: Kimsenin özel yaşamına, ailesine konutuna ya da haberleşmesine keyfi olarak karışılamaz, şeref ve adına saldırılamaz.

Avrupa İnsan Hakları Sözleşmesi'nin 8. maddesi: Herkes, özel ve aile yaşamına, konutuna ve haberleşmesine saygı gösterilmesi hakkına sahiptir.

Anayasa Madde 20: Herkes, özel hayatına ve aile hayatına saygı gösterilmesini isteme hakkına sahiptir. Özel hayatın ve aile hayatının gizliliğine dokunulamaz. Ek fikra: Herkes, kendisiyle ilgili kişisel verilerin korunmasını isteme hakkına sahiptir. Bu hak; kişinin kendisiyle ilgili kişisel veriler hakkında bilgilendirilme, bu verilere erişme, bunların düzeltilmesini veya silinmesini talep etme ve amaçları doğrultusunda kullanılıp kullanılmadığını öğrenmeyi de kapsar. Kişisel veriler, ancak kanunda öngörülen hallerde veya kişinin açık rızasıyla işlenebilir. 
- Öğrenmeyle sorumlu olmadığı şeylerin ardına düşmemek, ${ }^{3}$

- Başta aile içine ait olmak üzere sırları ifşa etmemek, ${ }^{4}$ zan ve gıybet gibi kişilere ait özel ve tüzel bilgileri bir başkasına taşımamak, menfaat amacıyla özel ve tüzel içerikli bilgilerin bir başkasına servis edilmesi mahiyetindeki fiillerden uzak durmak, ${ }^{5}$

- İnsanlara ait bilgiler ve bir takım özel haller üzerinden insanları çekiştirerek veya alay ederek özel hallerini açı etmemek ya da iftira gibi hiç olmayan şeylerle mahremiyetine zarar vermemek, ${ }^{6}$

- Kusur bulmak, ayıp ve açı̆̆ını yakalamak (tecessüs) gibi niyetlerle onların mahremiyetini araştırmamak (Hucurât 49/12),

- İnsanlara ait yazılı metin, defter, mektup gibi özel sayılabilecek evrakı izinsiz incelememek, ${ }^{7}$

- Ergenlik öncesi ve sonrası çağdaki çocuklar da dâhil olmak üzere yatak odalarına izinsiz girmemek ${ }^{8}$

- Bir grup arasında özel olduğu belli olan konuşmaları dinlememek, istemeden bunlara vakıf olunsa bile bunları ifşa etmemek ${ }^{9}$

- Evlere kapilarından izinle ve selamla girmek (Bakara 2/189), izin verilmediği müddetçe girmeye çalışmamak ${ }^{10}$ ve izinsiz içeri bakmamak (Buharî, Camiu's-Sahih, Diyat, 15).

"Bilmediğin şeyin ardına düşme; doğrusu kulak, göz ve kalp, bunların hepsi o şeyden sorumlu olur." (İsra 17/36)

4 Kıyamet gününde insanların Allah katında en fena olanı, karı-koca birbirine yakınlık olduktan sonra, kadının sırrını yayan erkektir." (Müslim, Nikâh, 124)

5 "Ey iman edenler! Zannın çoğundan sakının. Çünkü zannın bir kısmı günahtır. Birbirinizin kusurlarını ve mahremiyetlerini araştırmayın. Birbirinizin glybetini yapmayın." (Hucurât 49/12)

6 “İnsanları arkadan çekiştiren, gözle kaşla alay edenlerin vay haline!" (Hümeze 104/1)

7 "Kardeșinin yazılı metnine, onun izni olmadan bakan, ateşe (cehenneme) bakmış gibidir." (Ebu Davud, Salat, 23)

8 "Ey iman edenler! Ellerinizin altında bulunanlar (köleleriniz) ve sizden henüz büluğ çağına ermemiş olanlar, günde üç defa; sabah namazından önce, öğleyin elbiselerinizi çıkardığınız vakit ve yatsı namazından sonra (yanınıza girecekleri zaman) sizden izin istesinler. Bu üç vakit sizin soyunup dökündüğünüz vakitlerdir. Bu vakitlerin dışında (izinsiz girme konusunda) ne size, ne onlara bir günah vardır. Birbirinizin yanına girip çlkabilirsiniz. Allah, âyetlerini size işte böylece açılar. Allah hakkıyla bilendir, hüküm ve hikmet sahibidir. Nur 24/58-59)

9 "Her kim rızaları olmaksızın bir kavmin konuştuklarını dinlerse kıyamet gününde onun kulaklarına kurşun dökülecektir." (Tirmizî, Sünen, Libas, 19)

10 "Ey iman edenler! Kendi evlerinizden başka evlere, geldiğinizi hissettirip (izin alıp) ev sahiplerine selam vermeden girmeyin. Bu davranış sizin için daha hayırlıdır. Eğer evde kimseyi bulamazsanız, size izin verilinceye kadar oraya girmeyin. Eğer size, 'Geri dönün' denirse hemen dönün. Çünkü bu sizin için daha nezih bir davranıştır. Allah, yaptıklarınızı hakkıyla bilendir.” (Nur 24/27-28) 
Mahremiyetin diğer parçasını oluşturan ve cinsel istismar sorunuyla doğrudan ilgili husus ise bedenin mahremiyetidir. Kur'an'ın bedenin mahremiyetini korumaya yönelik ortaya koyduğu temel prensipler açısından şu ayet önemlidir: "Mü'min erkeklere söyle, gözlerini haramdan sakınsınlar, ırzlarını korusunlar. Bu davranış onlar için daha nezihtir. Şüphe yok ki, Allah onların yaptıklarından hakkıyla haberdardır. Mü'min kadınlara da söyle, gözlerini haramdan sakınsınlar, ırzlarını korusunlar. Görünen kısımlar müstesna, zînetlerini göstermesinler...” (Nur 24/30-31).

Ayet, cinsiyet farkı gözetmeksizin bedenin mahremiyetini korumaya yönelik iki ortak unsuru ortaya koymaktadır. Bunlar, yasaklanan kısımlara bakmamak ve bunları göstermemektir. Bu iki hususu, gözetleme ve teşhircilikten uzak durma şeklinde ortaya koyabiliriz. Mahremiyeti korumada ilk basamak ve iki taraflı düşünülecek öncelikli sorumluluk budur. Bakmak, göstermek ya da bedenini sergilemek konusundaki sınırları zorlayan eğilimler, cinsel istismar olaylarında kimi zaman görünen kimi zaman görünmeyen bir sebep olabilmektedir.

Bu noktada gözetleme ve teşhirciliği, bireysel bir problem olmaktan ziyade kitle iletişim araçlarının ayartmasıyla mahremiyet olgusunu zedeleyen ve toplumsal epidemiye dönüşmüş bir problem olarak görmek mümkündür. İnsan hayatında hiçbir mahremin veya gizliliğin kalmaması üzerine kurgulanmış olan modern teknolojinin postmodern sosyal iletişim ürünleri, kitleleri kendi ağı içinde her şeyi görmeye ve sergilemeye zorlamaktadır. Böylece bedenin mahremiyeti sosyal alana taşınmış olmaktadır. Sanal alanlarda gevşeyen mahremiyet algılarının gerçek toplumsal ilişkilere yansımaları ise, kitleleri daha görünür davranmaya itmektedir. Görünür olma kaygısı kitleleri hem izlemeye hem de izlenmeye sevk etmektedir. Mahremiyetin bireysel alandan toplumsal alana taşınması, görünürlüğü de postmodern bir değer haline getirmiştir. Burada görünürlüğün beden ve cinsellik üzerinden yaygınlaşması ise, mahremiyet eğitiminin işini zorlaştırmaktadır.

\section{Mahremiyet Eğitimi}

Mahremiyet eğitimi, çocuklara ve ergenlere kendisi veya karşı cinsin özellikleri hakkında bilgi sahibi olma, cinsiyete ilişkin rolleri anlama ve kabul etme, cinsel ihtiyaçlarını dinin, ahlakın ve kültürün belirlediği çerçevede gidermenin yollarını öğretmek amacıyla verilen eğitimdir (Diler, 2014, s. 79). Bir başka ifadeyle mahremiyet eğitimi, bireyin hem kendine ait özel alanını muhafaza edebileceği hem de diğerlerinin özel alanlarına saygı duyabileceği şekilde istek ve arzularını dini, ahlaki veya daha kapsamlı bir ifadeyle insani olarak eğitmektir. 
Cinsel istismar olgusunun önleme ve tedavi edilmesi hususunda mahremiyet eğitiminin hedefi, bireyin mahremiyetinin bireysel sınırlarında kalması gerektiğini öğretmek ve cinsel eğilimlerinin seyircilik, teşhircilik vs. gibi problemlere dönüşmeden diğer tutum ve tavırlarıyla bütünlük arz edecek biçimde normal sınırlarında yaşamasını sağlamak olmalıdır. Mahremiyet eğitiminin bu hedefi, sadece cinsel istismar olaylarının önüne geçmekle sınırlı olmayıp, hayatın bütününü kuşatıcı bir yaklaşımla insanlığa yakışan temel değerler merkezinde hayatı yaşamaya yöneliktir. Bu eğitimi yaparken erken çocukluk döneminden başlayarak hayatın bütününe yaymak gerekmektedir. Mahremiyet eğitimi, içinde cinsel eğitimi de kapsayan bir alandır. Bu sebeple gerek cinsel eğitim gerekse mahremiyet eğitimini kişilik eğitiminden ayrı düşünmemek gerekmektedir.

Mahremiyet eğitimi din eğitimi açısından düşünüldüğünde mutlaka iki duygunun eğitimini içermelidir. Bunlar iffet ve hayâ duygularıdır. İffet mahremiyet gibi evrensel bir değere anlam katan dini bir değerdir. Mahremiyetin önemli bir boyutunu ifade eden bir kavramdır. İffet insanın bedenî ve maddî hazlara aşırı düşkünlükten korunmasını sağlayan erdemdir. "Haramdan uzak durmak, helâl ve güzel olmayan söz ve davranışlardan sakınmak" anlamında olan iffet kelimesi, insandaki arzu ve şehvet gücünün ilımlı işleyişinden ortaya çıkar (Çağrıc1, 2000, s. 506). İffet eğitimi ise insanın yeme içme ve cinsî arzuları gibi istekleri konusunda ölçülü davranmasını, dinin ve aklın ilkeleri doğrultusunda aşırı isteklerini kontrol edebilmesini sağlama çabalarıdır.

Kur'an-1 Kerim'de "Evlenme imkânı bulamayanlar Allah'ın lütfu ile kendilerini yeterli imkâna kavuşturuncaya kadar iffetlerini korusunlar" (Nur 24/33) buyrulurken, $\mathrm{Hz}$. Peygamber de "Her kim ağzına ve cinsel arzularına hâkim olacağına dair bana söz verirse ben de onun cennete gireceğine kefil olurum."(Buhari, Rikak 23) şeklinde buyurarak bir yandan iffet erdeminin gereğini ortaya koyarken diğer yandan cinsel hayatın disiplinine ve eğitimine dikkat çekmiştir (Gündüz, 2011, s. 208).

İffet erdeminin kişiliğe yerleştirilmesinde gerekli olan duygulardan bir diğeri ise hayâdır. Mahremiyet için hayâ erdemini, bir başka kontrol mekanizması olarak düşünmek gerekir. Hayâyı, insanın önce Allah'tan, sonra insanlardan ve kendinden utanıp sinırlarına riayet etmesi olarak tanımlamak mümkündür. Burada utanmayı utanç duygusuyla karıştırmamak gerekir. Utanma fıtri ve sağlıklı bir duyguyu ifade ederken, utanç sağliksız bir duygudur. İnsanın kendini sevmemesi hatta kendinden nefret etmesine yol açan, aile ya da yetiştiği çevre baskısıyla ortaya çıkan, bir anlamda da kişinin sevdikleri tarafından psikolojik olarak terkedilmesinden kaynaklı bir duygudur (Cüceloğlu, 2001, s. 89). En olumsuz etkilerinden biri ise çocuğun iç dünyasına dönmesi ve aşağılık kompleksi oluşturmasıdır. 
İmanla ilişkili olduğu hadislerde de (Buhari, İman, 16) ifade edilen hayâ, sorumluluk sebebiyle yasaklanmış, kötü, ahlak dışı/günah olan şeylerden kaçınmak ve hoş olmayan şeyler yapınca utanmaktır (Erdem, 2016, s. 62). Bu nedenle iffet gibi hayâ duygusu da, açık ve gizli kötülük işlemekten alıkoyan, iyiliğe yönlendiren, mahrem olana karşı titizliğe ve mahremiyeti korumaya sevkeden önemli bir duygudur. Bu nedenle Kur’an, gayri meşru ilişkileri, gizli dost tutmayı, nikâhsız beraberlikleri (Maide 5/5), örtülmesi gereken mahrem yerleri örtmemeyi ve karşı cinsle konuşmalarda ölçüsüz davranmayı (Ahzab 33/32-33) iffet ve hayâ sınırlarını aşmak olarak değerlendirmiştir.

Yukarıda çerçevesi çizilen mahremiyet olgusunun, davranışa dönüşümünü sağlayacak olan mahremiyet eğitiminin temel ilkeleri şu şekilde sıralanabilir:

1. Mahremiyet eğitimini yasaklar üzerine kurmamak: $\mathrm{Bu}$ eğitimin amac1 narin, hassas olan utanma duygusunu utanca dönüşmeden yönlendirip beslemektir. Bunu yaparken çocuğun önce vicdanı eğitilmelidir. Vicdan insanın iyiyi kötülüklerden ayırt etmesine ve iyiyi bulmasına yardımcı olan yeteneğidir. Mahremiyet eğitimi vicdan eğitimiyle desteklenmelidir. Çünkü vicdanî gelişimini sağlıklı bir biçimde sağlayamamış bireyler, başkasının mahremiyet alanına girmekte sakınca görmez veya bu alanı kendi arzu ve beklentileri doğrultusunda manipüle etmeyi kendilerinde bir hak veya bunu bireysel bir özgürlük görürler.

2. Çocuk ve gençlere kişisel sınırlarını öğretmek: Ailede mahremiyet eğitiminin sağlayacağı hedeflerden biri de çocukların kişisel sınırlarını öğrenmesidir. Bu sınırların belirginleşmediği ailede yetişen çocuklar, hem kendi sınırlarının hem de başkalarının sınırlarının nerede başlayıp nerede bittiğinden emin olamazlar (Polat, 2001, s. 410). Küçükken kendi kişisel sınırları ihlal edildiğinden, öğrenilmiş bir davranış biçimi olarak kendileri de bunu yetişkinlikte tekrarlarlar. Bu yüzden mahremiyet konusunda çocuğa örnek olacak aile bireylerinin öncelikle kendi iffet ve hayâ duygularının zedelenmemiş olması gerekir.

3. Mahremiyet eğitimini sevgi üzerine inşa etmek: Anne-babanın saygilı ve empatik tutumları, cinsel içerikli olmayan sevgi gösterileri, çocuklarda küçük yaşlardan itibaren ailenin bir sevgi birimi olduğu fikrini benimsemesine ve kişinin kendisine ait bir eşe sahip olmasının çok özel bir durum olduğunu kavramasına ortam hazırlayacaktır. Anne-babanın kendi aralarındaki cinsel içerikli sevgi tezahürleri ne kadar mahrem olması gerekiyorsa, çocuklarına gösterecekleri sevginin de o kadar aleni olması gerekir. Çünkü çocuklar karşı cinsle ilişkilerini öncelikle ailede müşahede ettikleri bu ilişki biçimlerine göre düzenleme yoluna giderler. Hatta evlilik hayatlarında bile eşlerine muamelelerinde bu iletişim biçimlerinin etkisi az 
değildir. İşte anne-babalar gereksinim duydukları sevgileri onlara vererek ileride evlilik dışı cinsel faaliyetlerden koruyabilirler. Ayrıca yukarıda belirtildiği gibi ailede sevgi bakımından doyuma ulaşmış kişilerin cinsel istismar başta olmak üzere cinsellikle ilgili uç problemlere bulaşması daha az görülen bir durumdur. Ancak anne-babalar, ergenlik veya gençlik dönemindeki çocuklarına gösterdikleri sevginin çocuk tarafından cinsel yöne çekilmemesine dikkat etmeleri ve gereğinden fazla öpüp okşama tutumlarından uzak durmaları gerekir (Ziglar, 1998, s. 313). Eğer anne-babalar çocuklarından böylesi bir şeyden rahatsızlık duyuyor izlenimi alırlarsa bu davranış şeklini derhal değiştirmelidirler.

4. İzin alma eğitimi vermek: Mahremiyet eğitimi kapsamında çocuklara, evlere ve özel odalara girerken kapı çalma ve izin alarak girme eğitimi vermek gerekir. Önemi ayet ve hadislerde de vurgulanan bu hususlar, diğer insanlara ait uygunsuz manzaralara şahit olmanın önüne geçmek içindir. Böylesi olumsuz bir durum gerçekleşse bile paniğe kapılmadan kararlılıkla, olması gereken şey çocuktan istenmelidir. Sürpriz durumun sert tepkilerle karşılanması çocuğun zihninde bu manzaranin daha fazla yer etmesine zemin hazırlar.

5. Bedenlerin kişiye özel olduğu öğretmek: Çocuklara bedenin özel kısımlarının kimseye gösterilmemesi gerektiği ve bir başkasınınkine de bakmanın doğru olmadığını ifade etmek gerekir. Ayrıca sağlık gibi zorunlu haller dışında bu prensibin aile üyeleri ve yabancılar için aynı şekilde geçerli olduğu vurgulanmalıdır (Taşçı, 2010, s. 127). Bunun dişında tuvalet, banyo gibi mekânlarla birlikte kıyafet değiştirilen alanların da özel olduğu ve bir başkasının buralara girmemesi gerektiği konusundaki bilgiler, çocuklara mahremiyetle ilgili verilecek temel eğitimdir. Ayrıca aynı cinsiyetteki kardeşler arasında yatakların ayrılması, yine farklı cinsiyetteki kardeşler arasında da ilkokul çağıyla birlikte odalarının ayrılması beden mahremiyetini korumaya yönelik önemli yaklaşımlardır.

\section{6. Çocuğun cinsel içerikli sorularını, gelişimine uygun olarak cevaplan-}

mak: Çocuk üzerinde her zaman olumsuz etkileri görülmese bile, cinsellik konusunda vaktinden önce bilgi vermek yerinde bir davranış sayılmaz (Adler, 1998, s. 133). Bu tür soruları sorduğunda ötelemek ve geçiştirmek çocukların merakını daha da artırabildiği gibi ayıp karşılamak ise, onların cinselliği tümüyle kötü mevzular olarak algılamasına neden olur. Çocukların bu tür soruları esnasında atılacak ilk adım, çocuğun ne öğrenmek istediğinin belirlenmesidir. Bunun en basit yolu ise, bu sorunun cevabının ne olabileceğini tekrar ona sormaktır. Böylece çocuğun verdiği cevaptan neleri yanlış anladığı kolayca tespit edilir. Verilecek cevap ise bu doğrultuda bilgilerle desteklenerek çocuğa iletilir. Cevaplar çocuğun kavrama gücü- 
nün üstünde olmamalı ayrıca onda cinsel içgüdüyü kamçılayacak nitelikte olmamas1 gerekir (Adler, 1998, s. 180, 309).

7. Mahremiyet eğitimini karşılıklı güven temeli üzerine kurmak: Anne-babalar çocuğuna karşı açık sözlü, dürüst davranıp güvenilir olduklarını ona göstermeleri gerekir. Onun hayatındaki bütün ayrıntılara ve sırlara hâkim olmaya çalışmamalıdır. Çünkü ergenler ve gençler çok özel olmasa bile her şeyi ebeveyniyle paylaşmak istemezler. Ancak anne-babanın çocuğa ait her şeyi öğrenmedeki 1srarı, çocuğun aldatma eğilimine sapmasına neden olabilir. Ergen veya gençlerin kendine saklayabilecekleri ile anne-babalarıyla paylaşabilecekleri şeyler arasındaki farkı anlamaları konusundaki olgunlukları, mahremiyetlerine duyulan saygı ve onların anne-babalarına duydukları güvenle doğru orantılıdır.

8. Giyim-kuşam konusunda sınırları öğretmek: Bu konuda önce anne-babalar kendi ev içi ve ev dışı giyimlerinde bu sınırları önemseyerek çocuklara örneklik göstermelidirler. Kendi mahrem alanına girmeye davetiye çıkaran, vücudu sararak teşhire yönelik bir amaç taşıyan giyim anlayışından uzak durmalıdır. Çünkü böylesi bir giyim tarzı kimi zaman insanlar tarafından "neler elde edebileceğinizi görün" (Ziglar, 1998, s. 301) şeklinde bir davet mesajı olarak algılanabildiği gibi, insanların gözleriyle onun bedenine dokunmasına neden olabilir.

9. Beğenilme arzusu yerine ihtiyaç odaklı giyinmek: Giyinmenin beğenilme arzusuyla ve başkaları için değil, ihtiyaç odaklı ve kendisi için olması gerektiği anlayışı, mahremiyet eğitimindeki temel hususlardan biridir. Moda zihniyetinin mahremiyet için bir tehdit olduğu unutulmamalıdır. Bu anlamda moda, sürekli değiştirerek sunduğu ürünler yoluyla tüketimci bir toplum yapısını pekiştirirken, öte yandan mahremiyet hususundaki algıların yumuşak bir biçimde değişmesine olanak sağlar. Hem ihtiyaç odaklı bir örtünme yerine dikkat çekme ve ilgi odağı haline dönüştürme aracı olan modanın duruşu, hem de modanın görünür olmasını sağlayan TV ve medyanın dinin öngördüğü mahremiyet yerine, serbest cinsel yaşam ve haz odaklı rahat ilişkiler öngörmesi mahremiyet algısında olumsuz değişimlere yol açmaktadır.

10. Karşı cinsle ilişkileri konusunda hassas olmak: Ergenlik ve gençlik döneminde karşı cinsle ilişkiler ve arkadaşliklar hususunda ebeveynler hassas davranmak durumundadır. Bu münasebetlerin mahrem alanlara saygı duyularak gerçekleşmesi gerektiği üzerinde durulmalıdır. Gelişim dönemleri itibariyle bu dönem ilişkileri gevşemeye ve laubaliliğe müsaittir. Bu laubaliliklerin mahrem alanları ufak ufak ihlale sebep olabileceği gençlere uygun bir iletişim diliyle söylenmelidir. Ayrıca ilgi görmek insanın hoşlandığı ve bundan etkilenebileceği bir durumdur. Bu durum özellikle gençlik döneminin bir ihtiyacıdır (Jersıld, 1974, s. 245). İlginin oluştura- 
bileceği etkinin de mahremiyeti çiğnemeye yönelik olması ihtimali göz ardı edilmemelidir. Ayrıca medyanın özendirmelerle ihtiyaç biçiminde gençliğe empoze ettiği yakın duygusal arkadaşlık ilişkilerini içeren "flört"lerin de mahremiyet sınırlarını zorladığı hatta kimi zaman da mahremiyetin çiğnenmesine neden olarak evlilikler için güvensizlikler oluşturduğu konusunda gençler duyarlılık kazanmalıdır.

11. TV ve internet kullanımını sınırlandırmak: Mahremiyet eğitimi kapsamında çocuk, ergen ve gençlerin TV ve internet kullanımları mutlaka belirli kurallar çerçevesine sokulmalıdır. Sınırsız kullanım özgürlüğü vermekten kaçınılmalıdır. Gereğinden çok kullanımlarda uygunsuz görüntülerle karşılaşma riski artmaktadır. $\mathrm{Bu}$ anlamda bilgisayarı çocuk odalarında değil genel odaların birinde kullandırmak daha uygun bir yaklaşımdır. Ayrıca uygunsuz görüntüleri bloke edici programlar kullanmak, TV ve interneti daha güvenli hale getirilebilir (Taşç1, 2010, s. 130).

\section{Sonuç}

Ülkemizde yapılan araştırmalar cinsel istismar oranlarının giderek arttığını ortaya koymakla birlikte, toplumda gizli olarak seyreden bu olgunun gerçek boyutlar1nın mevcut rakamların çok ötesinde olduğunu düşündürmektedir. Cinsel istismar vakalarının mağdur kitlesi çocuklar ve kadınlardan oluşmaktadır. Bundan daha kötüsü ise, bu mağdur kitle üzerinde gerçekleşen istismarların üçte birinden fazlasının yakınlar tarafından gerçekleştirilmiş olmasıdır. Buna göre cinsel istismar olgusunun azımsanamayacak derecede bir oranını ensest vakaları oluşturmaktadır. Oysa bütün genel ahlak ilkeleri ve dini prensipler açısından yasaklanan bu durumun Müslüman toplumda giderek artması, problemin ciddi olarak ele alınmasını gerektirmektedir.

Cinselliğin bireysel ve sosyal ruh sağlığına olumsuz etkilerinin giderek artması, yaşamın inanç ve değer odağından uzaklaşması ve gelişen teknolojiyle beraber tüketimi merkeze alan bir hale dönüşümüyle doğrudan ilgilidir. Bu dönüşümle beraber dinin; huzurlu, dengeli, ruh sağllğı yerinde bir toplum için koyduğu bireysel ve sosyal sınırlamalar zarar görmektedir. Sonuçta bu manzara karşısında çocukların ve gençlerin; dini, sosyal ve psikolojik açıdan sağlıklı bir gelişim göstermelerini beklemek gerçekçi bir yaklaşım olmayacaktır. Ahlaki suçların sadece hukukî cezalarla önlenemeyeceği aşikârdır. Bu tür problemlerin suça dönüşmeden engellenmesi, mahremiyet gibi değerlerin kazandırılması ve bu konudaki duyarllıkların mütemadiyen sürdürülmesiyle mümkündür.

Toplumda cinsel istismar vakalarındaki artışı mahremiyet olgusuyla ilintili düşünmek gerekir. Çünkü mahremiyet, insanın isteklerini ahlaki ve dini sınırlarda 
tatmin etmesine yardım eden bir erdemdir. Bu erdemdeki olumsuz değişimler, cinsel istismar gibi bazı eğilimlerin toplumdaki artışına kaynaklık oluşturabilmektedir. Cinsel istismarın aile, medya gibi boyutları kendi içinde özel olarak irdelenmesi gereken alanlardır. Ancak her iki alanla doğrudan ilgili olan önemli bir faktör mahremiyet olgusudur. Aile ve medyanın mahremiyet ve eğitimiyle doğrudan sebep-sonuç biçiminde bir ilişkisi vardır. Mahremiyet insanlığın önemli bir parçası olarak doğrudan cinsiyetle ilgili değildir. Bu yüzden mahremiyet eğitimini yalnız kadın ve kız çocuklarının eğitimi gibi düşünmek doğru olmaz. Nasıl ki cinsel istismar probleminin kaynaklarından biri cinsel kimlik oluşumundaki problemlerdir, o halde mahremiyet eğitimi de cinsiyet ayrımı olmaksızın kişilik eğitimiyle doğrudan ilgilidir. Din eğitimi açısından mahremiyet eğitimi ise, iffet ve hayâ gibi iki temel değer merkezine inşa edilmelidir. Bu değerler Kur'an'ın mahremiyet merkezine koyduğu temel unsurlardır. Bu şekliyle mahremiyet eğitimi, teşhircilik ve gözetleme gibi cinsel istismara kaynaklık eden eğilimlerin önüne geçmek için vardır. Cinsel eğitimi de içine alan mahremiyet eğitiminin genel amacı, kişinin hayatını hem kendi sınırlarını gözeterek hem de başkalarının sınırlarına riayet ederek yaşanmasına zemin oluşturmaktır. 


\title{
The Phenomenon of Sexual Abuse and Privacy Education
}

\author{
Adem Güneş
}

\section{Introduction: Definition and Prevalence of Sexual Abuse}

Sexual abuse is more harmful than many other types of abuses in terms of its' physical and emotional impact. This phenomenon is defined as use of women and children who have completed psychological development for sexual satisfaction by adult individuals (Kara, Biçer \& Gökalp, 2004, p. 143). Another definition of sexual abuse is verbal abuse where someone uses all kinds of words and behavior with sexual content which may directly or indirectly violate the privacy of a person.

Sexual abuse does not have to be touching, but many non contact behavior is also included. It is a widespread phenomenon that involves many elements such as women's trade, prostitution, harassment, rape, pedophilia, incest, exhibitionism and voyeurism, verbal abuse, unsolicited opportunistic touches, pornographic speech, sexual profanity (Polat, 2007, p. 24; Aktaş, 2006, p. 34).

Statistics globally and in our country reveal the prevalence of sexual abuse cases. According to the World Youth Report, more than one-third of girls aged 15 and under are sexually assaulted. Each year, as a result of these cases that occur in childhood, 15 million girls are giving birth (The World's Youth, 2000). According to another world-wide survey, one out of every 4 girls and one out of every six boys who have been sexually abused, are abused before the age of 18 (NSVRC, 2017).

Surveys and some official data reveal that sexual abuse is increasing in our country. According to the Ministry of Justice, 12,720 children in 2009, 16,354 children in 2011, 16,897 children in 2012 and 16,938 children in 2013 were ex- 
posed to sexual abuse in our country (Ministry of Justice Criminal Record and General Directorate of Statistics, 2013). Despite these official figures, it is estimated that the data on cases of sexual abuse in our country still has not fully appeared.

According to research data, the most important victims are children, as in other types of abuse. "Incest" is the generates big physiological or psychological problems that the child or the woman may encounter in life. Incest, is considered a domestic sexual abuse. Incest is the sexual rapprochement between persons and their marriages are not legitimate religiously, legally and morally (TDK, 2011, p. 802; Kirman, 2000, p. 73). In our country, according to the results of limited domestic sexual abuse cases reflected in the courts, these abuses come from the father, stepfather, brother, uncle and other relatives respectively. In addition, abuses where stepfathers play a role can be heavier and have longer impact than others (Topçu, 1997, p. 96).

\section{Factors Increasing the Sexual Abuse and Incest Problem}

The rates of domestic sexual abuse in our society is increasing. This phenomenon, which contradicts all religious values and moral principles, has been off the agenda for many reasons. In cultural tradition sometimes it is thought of as something that is caused by a victim. Islam absolutely forbids this. The following factors are generally influential to the increase of sexual abuse and domestic sexual abuse:

Changes in family structure and perception and parental attitudes,

The effect of increasing and uncontrolled sexual stimulants,

Sexual identity problems,

Weakening religious-moral-social values in the face of the consumer mindset, Changes in the perception of privacy.

The problem is addressed below in terms of these factors.

\section{Sexual Identity Problems and Parental Effects}

Sexual identity or gender roles include behavior that can be labeled masculine or feminine, attitudes, values, ways of thinking, speaking, sitting or walking, dressing, and ornamenting a person's body. Individuals learn to understand gender identities as men and women from an early age. The most important share in this development belongs to parents and social-cultural influences (Gander \& Gandier, 1995, p. 296). 
Sexual assaults have a direct relationship with sexual identity. These assaults are not actions that suddenly occur in the name of relieving your sexual need and tension (Atkinson \& Hilgard, 2003, p. 378). This situation is a personality problem of the exploiter, it has planned in advance. In such a mood, it is preferable to be satisfied with a sadistic way of sexual desires that can not be satisfied normally.

According to a survey among juvenile delinquents, $7 \%$ of young people were found to be sexually obsessed. The proportion of sexual offenders is $31 \% .60 \%$ of the sex offenders are homosexual offenses, the rest are followed by such crimes as rape and girl abduction (Yavuzer, 1998, p. 197). Sexual offenders usually come from families whose love and discipline are deficient and where neglect exists. According to their own expression, they have not seen enough love. Their personalities were not respected, they were persecuted and tortured (Çağlar, 1981, p. 181).

As the examples point out, an important factor in the emergence of sexual deviation and crimes is the "sexual identity problem". The foundations of sexual identity are established at very early ages. When they reach the age of three, children become aware of their gender, even tend to boast of their gender. The formation of sexual identity that begins in this age as emotion and behavior lasts until puberty (Jersild, 1979, p. 210). Sexual identity problems, which we point out as a risk factor for sexual crime and abuse, are mainly linked to the parent's sexual identity and personality. If parents want to have a healthy sexual identity in their children, they must first ensure that their sexual identity and personalities are based on normal lines and privacy.

\section{Sexual Stimulants and Effects of the Media}

Another of the risk factors that lead to increased incidences of sexual abuse is sexual stimulants, especially coming from the media. Children, young or adult individuals are all exposed to intense sexual stimulus in the world we live in. These stimulus are sometimes transmitted through clear, direct visuals, and sometimes more hidden and subconscious messages.

In today's modern societies, nearly all areas of Privacy are publicized and bodies are consumed. According to capitalism, the body is an important and constantly consuming field. Capitalism carries out a form of postmodern exploitation by making consumption over bodies. For the sake of consumption, the bodies are crumbling, the privacy is being destroyed and the bodies are being dashed (Okumuş, 2011, p. 54). The fact that consumption is over bodies means that we encounter sexuality more often. Hedonistic understanding constitutes a hidden depersonalization in the area of individual and social responsibility demeaning religious life and morality. Every year with out represanting sexuality directly, hundreds of 
thousands scenes with sexual connotations are shown on the TV. In this situation, TV gives the message that there is no a problem in sexuality exceeding the boundaries a little.

An important factor contributing to the increase of sexual abuse incidents is the internet. There is an uncontrolled area on this global network, where sexuality and even pornography dominate, creating a risk for everyone, not just for children and young people. This pornographic area is a field that produces sexual desires at the extremities. Pornography is the process of overcoming the normal limits of sexuality and subjecting the female body to exploitation as a consumed commodity (Kahraman, 2010, p. 198). Pornography is a problem creating artificial incitement and addiction in terms of mental health. This addiction can disrupt young people's perceptions of privacy and lead them to sodomy.

\section{Changes in Privacy Phenomenon}

One of the most important reasons for sexual abuse is the changes in privacy. Privacy is concerned with the concept of "private" in a special sense. It is a religious concept that means "being haram or forbidden". Mahrem (private) is also used for those who Allah has forbidden to marry (DIB, 2010, p. 402).

Privacy means a private and protected area of the individual. Privacy is a universal concept phenomenon. With regard to the protection of privacy there are many principles offered in the Qur'an and by the Prophet Muhammed. There is a verse in the Qur'an concerning the protection of Privacy: "Say to the believing men that they should lower their gaze and guard their modesty: that will make for greater purity for them: and Allah is well acquainted with all that they do.." (Light, 24/30-31) The verse reveals two common elements to protect the privacy of the body regardless of gender. This is not to look at the prohibited parts and do not show them. Or keep them away from surveillance and exhibitionism. This is the first step in protecting privacy and the primary responsibility to be considered bilateral.

\section{Privacy Education}

Privacy education is basically training the individual's requests and desires. With privacy education, children and young people are taught to define their gender characteristics, to accept gender roles, and to fulfill their sexual needs with in religion, ethics and culture (Diler, 2014, p. 79). The goals of privacy education in prevention and treatment of sexual abuse; to teach that the privacy of the individual 
must be respected and protected, to ensure that sexual tendencies are kept within their normal limits without turning into problems such as spectatorship, exhibitionism, etc. This goal of privacy education is not only limited to the prevention of sexual abuse incidents, but it is also aimed at life in the center of basic values that fit humanity with a comprehensive application. It is necessary to extend this education from the early childhood period throughout the whole of adult life.

Privacy education is a field that also includes sexual education. For this reason, sexual and privacy education needs not to be considered separately from personality education. Privacy education should include education of two senses when it is considered in terms of religious education: These are chastity and shame emotions.. Chastity is a religious value that adds meaning to a universal value like privacy. It is a concept that expresses an important dimension of privacy. Chastity is the virtue that protects the person from extreme devotion to physical and material pleasures. Chastity normalizes desire and lust (Çağrıc1, 2000, p. 506).

A few basic principles of privacy education can be listed as follows:

1. Not to establish privacy education merely on prohibitions,

2. To teach personal boundaries to children and young people,

3. To build privacy education on love,

4. To encourage door knocking and permission asking education,

5. To teach that bodies are private etc..

\section{Conclusion}

Research in our country shows that the rates of sexual exploitation are increasing steadily and that the true dimension of this phenomenon which is hidden in society is far beyond these figures. The victims of sexual abuse cases consist of women and children. Even worse than this is that more than a third of the abuses on these victims have been made by relatives. According to this, a significant proportion of sexual abuse cases constitute incest cases. The increase of this situation which is banned in terms of all general moral principles and religious principles in Muslim society requires that the problem be taken seriously.

With the increase in the sexual abuse cases in the society, it is necessary to think in relation to privacy. Because privacy is a virtue that helps people satisfy their wishes inside moral and religious boundaries. Negative changes in this virtue can lead to increase in some trends such as sexual abuse in society. It is obvious 
that moral offenses carn not be prevented only by legal punishment. The prevention of such problems before they convert into crime is elated to the power of privacy education in society. Privacy as an important part of mankind and can not be thought of as only related to a single gender. In terms of religious education, privacy education should be done without sex discrimination. Chastity and modesty are the two important values that religious education gives in basics of privacy education. In this way, privacy education is there to prevent tendencies that create sexual abuse such as exhibitionism and surveillance.

\section{Kaynakça | References}

Adler, A. (1984). Çocuk Eğitimi. İstanbul: Cem Yayınları.

Aktaş, A. (2006). Aile İçi Şiddet Kadının ve Çocuğun Korunması. Ankara: Elma Yayınevi.

Atkinson, R. C., \& Hilgard, E. R. (2003). Introdaction to Psychology. New York: Thomson Learning.

Aydın, M. (2009). Mahremiyet ve Örtünmenin Dönüşümü. Eski-Yeni, 12, 61-67.

Canatan, K. (2011). Beden Sosyolojisi. İstanbul: Açılım Kitap.

Cline, V. (2017, 14 Mayıs). Pornografinin Zararları. https://wol.jw.org/tr/wol/d/r22/lp-tk/102003523 adresinden edinilmiştir.

Cüceloğlu, D. (2001). İçimizdeki Çocuk. Ankara: Remzi Yayınları.

Çağlar, D. (1991). Uyumsuz Çocuklar ve Eğitimi. Ankara: AÜEF Yayınları.

Çağrıcı, M. (2000). Iffet. DİA içinde (c. 21, s.506-507). Ankara: Diyanet İşleri Başkanlığı Yayınları.

DİB. (2010). Dini Kavramlar Sözlüğü. Ankara: Diyanet İşleri Başkanlığı Yayınları.

Diler R. (2014). Mahremiyet Eğitimi ve Önemi. GOPÜİFD, 2(1), 69-98.

Erdem, H. (2016). Mahremiyet, İffet, Hayâ İlişkisi. Din Gelenek ve Ahlak bağlamında Mahremiyet Algıları Sempozyumu (I) içinde (s.53-66). Samsun: Ordu İlahiyat Vakfı Yayınları.

Fromm, E. (2011). İnsanda Yıkıcılığın Kökenleri II. İstanbul: Payel Yayınları.

Gander, J., \& Gandiner, W. (1995). Çocuk ve Ergen Gelişimi. Ankara: İmge Kitabevi.

Giddens, A. (2005). Sosyoloji. Ankara: Ayraç Yayınları.

Gündüz, T. (2011). Ailede Cinsel Eğitim. İstanbul: Timaş Yayınları.

Güvenli İnternet Kullanımı. (2012, 17 Ekim). BTK, http://www.btk.gov.tr/kutuphane_ve_veribankasi/raporlar/ arastirma_raporlari/index.php adresinden edinilmiştir.

Jersıld, A., \& Özgür, İ. (1974). Gençlik Psikolojisi. İstanbul: Gün Matbaası.

Jersild, A. (1979). Çocuk Psikolojisi. (G. Günçe, Çev.) Ankara: AÜEFY.

Kahraman H. B. (2010). Cinsellik, Görsellik, Pornografi. İstanbul: Agora Kitaplığı.

Kara, B., Biçer Ü., Gökalp A. S. (2004). Çocuk İstismarı, Çocuk Sağllğı ve Hastalıkları Dergisi, 47(2). 140-151.

Kasapoğlu, A. (2003). Ensest Tabusu ve Egzogami Kuralının Kur’an'daki Yansımaları, Dinbilimleri Akademik Araştırma Dergisi, 3(1), 5-15.

Köknel, Ö. (2013). Şiddet Dili. İstanbul: Remzi Kitabevi.

KSGM. (2009). Türkiye’de Kadına Yönelik Aile İçi Şiddet Araştırması, Ankara. 


\section{The Journal of Humanity and Society}

MEB. (1996). Türkçe Sözlük, İstanbul: Milli Eğitim Basımevi.

Okumuş, E. (2011). Bedene Müdahalenin Sosyolojisi. Kadir Canatan (Ed.), Beden Sosyolojisi içinde (s. 45-66). İstanbul: Açılım Kitap.

Pernaud, L. (1987). Çocuğun Cinsel Eğitimi. (K. Denizyaran Çev.) Ankara: e Yayınları.

Polat, O. (2001). Çocuk ve Şiddet. İstanbul: Der Yayınları.

Polat, O. (2007). Tüm Boyutlarıyla Çocuk İstismarı. Ankara: Seçkin Yayınları.

Saad G. (2011). Tüketim İçgüdüsü. (N. Özata Çev.) İstanbul: MediaCat Yayınları.

Santrock, J. W. (2014). Yaşam Boyu Gelişim Psikolojisi (13.Baskı). Ankara: Nobel Yayıncılık.

Savrun, M. (2009). Bir Ahlak Sorunu Olarak Cinsel Taciz. IV. Din Şurası içinde (s. 568-572). Ankara: DİB Yayınları.

Sexual Violance Against Youth \& Young People. (2017, 18 Mayıs). NSVRC, http://www.nsvrc.org/projects/lifespan/sexual-violence-against-youth-young-people adresinden edinilmiştir.

Taşçı, A. İ. (2010). Cinsel Eğitim. İstanbul: İz Yayıncılık.

Topçu, S. (1997). Gençlerin ve Çocukların Cinsel İstismarı. Ankara: Doruk Yayıncılık.

Vitale, J. (2008). Kelimelerle İkna Etmenin Yolları-Tüketicileri Hipnotize Eden Metin Yazma Teknikleri (Z. Yaman Çev.) İstanbul: MediaCat Yayınları.

WHO. (2002). Child Abuse in World Report on Violence and Health (p. 57-81). Geneva: WHO Publications.

Yanık, M. (2000). Psikiyatri Polikliniğine Başvuran Hastalarda Unutulmuş Çocukluk Çağı Tacizlerini Yeniden Hatırlamanın Sıklı̆̆ı. (Uzmanlık Tezi). Cerrahpaşa Tıp Fakültesi, İstanbul.

Yavuzer, H. (1998). Çocukve Suç. İstanbul: Remzi Kitabevi.

Ziglar, Z. (1998). Olumsuz Bir Dünyada Olumlu Çocuklar Yetiştirmek. İstanbul: Beyaz Yayınları. 